\title{
LEVEL OF PHYSICAL ACTIVITY AND PAIN SCALE IN ELDERLY AT POSYANDU LANSIA MEKAR SARI SURABAYA
}

\author{
Adela S Sampouw ${ }^{1)}$, T. Arief Dian ${ }^{2)}$, FX Himawan H. Jong ${ }^{3)}$
}

\begin{abstract}
Introduction : The increasing number of elderly life expectancy has caused health issues. The majority of elderly have dealt with a pain issue. Furthermore, the pain can affect their physical activities.

Aim : This study aimed to analyze the relationship between elderly physical activity level with pain scale.

Methods : An observational analytical study with a cross sectional approach was used for the study. The respondents were elderly people who visited Posyandu Lansia Mekar Sari Surabaya from $29^{\text {th }}$ July until $11^{\text {th }}$ October in 2017. Data of physical activities were collected by interviewing the respondents with questions taken from International Physical Activity Questionnaire (IPAQ). They were also asked to point which scale matched their pain problem best on the Numeric Rating Scale (NRS) card. The results of the questionnaire was examined by Rank Spearman Test.
\end{abstract}

Result : There was no significant relationship found in between the two variables $(p=0,328)$.

Conclusion : The elderly people at Posyandu Lansia Mekar Sari Surabaya were active and mostly has mild and moderate scale of pain.

Keywords : Physical activity, pain scale

1) Student of Faculty of Medicine, Widya Mandala Catholic University Surabaya, Kalisari Selatan 1 Surabaya Email: Adelasampouw@gmail.com

2) Surgery Department Faculty of Medicine, Widya Mandala Catholic University Surabaya, Kalisari Selatan 1 Surabaya

3) Anatomy and Histology Department Faculty of Medicine, Widya Mandala Catholic University Surabaya Kalisari Selatan Surabaya 


\section{INTRODUCTION}

Global predictions show that the population of elderly people will continue to increase. The elderly population in Indonesia is predicted to increase higher than the elderly population in the Asian region and globally after 2050. The Ministry of Health of the Republic of Indonesia published a paper saying that Indonesia is a country with elderly structure, this can be seen from the percentage of elderly people in 2008, 2009 and 2012 has reached above $7 \%$ of the total population. ${ }^{(1)}$

In 2000 the number of elderly people was projected at $7.28 \%$. The Department of Health collected data from 2004-2015 showing an increase in life expectancy in Indonesia from 68.6 years to 70.8 years and projections for 2030-2035 reaching 72.2 years. $^{(2)}$

Pain is a common complaint felt by the elderly. As the elderly population increases, chronic diseases associated with pain will increase. This chronic pain did not get treatment or usually was treated inadequately. This can have a negative impact on the health and quality of life of elderly. Depression, anxiety, isolation from social life, decreased cognitive abilities, immobility, and sleep disorders can arise due to inadequate management of pain. $^{(3)}$
One third of the elderly in the world have experienced chronic pain, which disrupts a normal function. ${ }^{(4)}$ Elderly tend to have arthritis, bone and joint complaints, cancer, and other chronic diseases associated with pain. ${ }^{(3)}$ This is important because pain is very subjective. $^{(4)}$

The problem of this condition in the elderly is the difficulty to establish a diagnosis and determining therapy. The main causes of these failures were some improper beliefs: that pain in elderly is something normal and does not need professional medical treatment, pain in elderly are better because adult usually can tolerate the pain better than the young so it does not need special treatment, and chronic pain is not dangerous. ${ }^{(5)}$

Pain prevalence in elderly based on several studies was $65-80 \%$ and most of them needed hospital treatment because they suffered from pain. Data from the National Health Interview Survey (NHIS) conclude that 25.3 million people in America suffer from pain every day. 23.4 million people reported experiencing severe pain, while 14.4 million people experienced severe pain in category four. This makes them need medical treatment, have poor medical status, and experience more disability than someone with a lighter scale of pain. ${ }^{(6)}$ 
Physical activity according to the World Health Organization (WHO) is any body movement produced by skeletal muscles that requires energy expenditure. Physical activity for the elderly includes activities in leisure time, transportation, work, doing homework, and activities related to a community. To improve the health of the body system, the elderly need to do physical activities such as aerobics, balance exercises, and activities that increase muscle strength on a regular basis every day, but with the environment and conditions that are less favourable due to the onset of pain, this type of physical activity can be difficult ${ }^{(7)}$

\section{METHODS}

This study was an observational analytic study with cross sectional study design. The subject in this study were patients of the Posyandu Lansia Mekar Sari Surabaya in June-July 2017. Based on this, there were 42 respondents who met the criteria.

Respondent's data was collected and interview was conducted to determine the level of physical activity and pain scale. Interviews were conducted only on respondents who met the inclusion criteria and by using IPAQ and NRS questionnaires. The process of collecting information and data was carried out on July 29 to 11 October 2017 .

\section{RESULT}

Table 1. Gender Distribution

\begin{tabular}{ccc}
\hline Gender & $\begin{array}{c}\text { Frequency } \\
(\mathrm{n})\end{array}$ & $\begin{array}{c}\text { Percentage } \\
(\%)\end{array}$ \\
\hline Man & 6 & $14,0 \%$ \\
Woman & 37 & $86,0 \%$ \\
\hline Total & 43 & $100 \%$ \\
\hline
\end{tabular}

In the table above the total respondents of this study were 43 people. The results showed that there were more female respondents $(86.0 \%)$ than male respondents (14.0\%).

Table 2. Age distribution

\begin{tabular}{ccc}
\hline Age & $\begin{array}{c}\text { Frequency } \\
(\mathrm{n})\end{array}$ & $\begin{array}{c}\text { Percentage } \\
(\%)\end{array}$ \\
\hline $\begin{array}{c}\geq 60-64 \text { years } \\
(\text { Early age })\end{array}$ & 16 & $37,2 \%$ \\
$>65$ years \\
$(($ Elderly $)$ \\
$>70$ years \\
$\begin{array}{c}\text { (Elderly are } \\
\text { at risk })\end{array}$ & 9 & $20,9 \%$ \\
\hline Total & 18 & $41,9 \%$ \\
\hline
\end{tabular}

The research subjects taken were elderly aged $\geq 60$ with grouping according to the UU Kesejahteraan Sosial No. 13 of 1998 with a frequency of Early Elderly ( $\geq$ 6064 years) of 16 people (37.2\%), Elderly (>65 years) 9 people (20.9\%), and elderly at risk ( $>70$ years) 18 people $(41.9 \%)$. The results of the age frequency table indicate that of the 43 respondents the Elderly at risk have the highest number $41.9 \%$. 
Table 3. Distribution of Physical Activity Levels

\begin{tabular}{|c|c|c|}
\hline $\begin{array}{l}\text { Level of } \\
\text { Physical } \\
\text { Activity }\end{array}$ & $\begin{array}{l}\text { Frequency } \\
\text { (n) }\end{array}$ & $\begin{array}{c}\text { Percentage } \\
(\%)\end{array}$ \\
\hline $\begin{array}{c}<300 \mathrm{MET} \\
\text { (Light) }\end{array}$ & 6 & $14,0 \%$ \\
\hline $\begin{array}{l}\geq 300 \text { MET } \\
\text { (Medium) }\end{array}$ & 25 & $58,1 \%$ \\
\hline $\begin{array}{c}\geq 6000 \mathrm{MET} \\
\text { (Weight) }\end{array}$ & 12 & $27,9 \%$ \\
\hline Total & 43 & $100 \%$ \\
\hline
\end{tabular}

Based on table 3, from 43 of elderly respondents that have moderate activity level was $58.1 \%$, while the elderly with mild activity levels have the lowest percentage of $14.0 \%$.

Table 4. Pain Scale Distribution

\begin{tabular}{ccc}
\hline Pain Scale & Frequency (n) & $\begin{array}{c}\text { Percentage } \\
(\%)\end{array}$ \\
\hline 0 (painless) & 6 & $14,0 \%$ \\
$1-4$ (Light) & 15 & $34,9 \%$ \\
$\begin{array}{c}5-6 \\
\text { (Moderate) }\end{array}$ & 15 & $34,9 \%$ \\
$\begin{array}{c}7-10 \\
\text { (weight) }\end{array}$ & 7 & $16,3 \%$ \\
\hline Total & 43 & $100 \%$ \\
\hline
\end{tabular}

Table 4 show that the elderly with mild and moderate pain scale had the same percentage of $34.9 \%$ with a frequency of 15 people. The lowest frequency was elderly with a scale of 0 pain or no pain with a percentage of $14.0 \%$.
Table 5. Distribution of Physical Activity Levels and Pain Scale

\begin{tabular}{|c|c|c|c|c|c|}
\hline \multirow[b]{2}{*}{$\begin{array}{l}\text { Level of } \\
\text { Physical } \\
\text { Activity }\end{array}$} & \multicolumn{4}{|c|}{ Pain Scale } & \multirow[b]{2}{*}{ Total } \\
\hline & $\begin{array}{l}\text { No } \\
\text { pain }\end{array}$ & Light & $\begin{array}{l}\text { Medi } \\
\text { um }\end{array}$ & Weight & \\
\hline Light & $\begin{array}{c}0 \\
(0 \%)\end{array}$ & $\begin{array}{c}1 \\
(2,3 \%)\end{array}$ & $\begin{array}{c}3 \\
(7 \%)\end{array}$ & $\begin{array}{c}2 \\
(4,7 \%)\end{array}$ & $\begin{array}{c}6 \\
(14 \%)\end{array}$ \\
\hline Medium & $\begin{array}{c}4 \\
(9,3 \\
\%)\end{array}$ & $\begin{array}{c}10 \\
(23,3 \% \\
)\end{array}$ & $\begin{array}{c}8 \\
(18,6 \\
\%)\end{array}$ & $\begin{array}{c}3 \\
(7 \%)\end{array}$ & $\begin{array}{c}25 \\
(58 \%)\end{array}$ \\
\hline Weight & $\begin{array}{c}2 \\
(4,7 \\
\%)\end{array}$ & $\begin{array}{c}4 \\
(9,3 \%)\end{array}$ & $\begin{array}{c}4 \\
(9,3 \\
\%)\end{array}$ & $\begin{array}{c}2 \\
(4,7 \%)\end{array}$ & $\begin{array}{c}12 \\
(28 \%)\end{array}$ \\
\hline Total & $\begin{array}{c}6 \\
(14 \% \\
)\end{array}$ & $\begin{array}{c}15 \\
(35 \%)\end{array}$ & $\begin{array}{c}15 \\
(35 \% \\
)\end{array}$ & $\begin{array}{c}7 \\
(16 \%)\end{array}$ & $\begin{array}{c}43 \\
(100 \%)\end{array}$ \\
\hline
\end{tabular}

From the table above, it can be seen that there is no elderly with mild activity levels who do not experience pain with a percentage of $0 \%$, and the highest percentage for the scale of pain 0 is occupied by moderate activity levels of 4 people with a percentage of $9.3 \%$. The highest percentage for mild pain was experienced by the elderly with moderate activity levels with a percentage of $23.3 \%$ of 10 people, while moderate pain was experienced by the elderly with moderate levels of physical activity of $18.6 \%$ of 8 people. Severe scale pain is experienced by the elderly with a moderate level of physical activity 3 people (7\%).

Spearman Rank test was used to determine the relationship between the level of physical activity and the scale of 
pain in the elderly at the Posyandu Mekar Sari Surabaya because the measuring scale of the two variables was ordinal. The results of Rank Spearman test obtained $p=$ 0.328 , this means that $p>\alpha(\alpha=0.05)$ so that it can be concluded there is no relationship between the level of physical activity and the scale of pain.

\section{DISCUSSION}

In this study, female was higher than male with a percentage of $86 \%$ and $14 \%$. This statement is supported by data by the Central Statistics Agency (BPS) of Surabaya City that for 3 consecutive years the number of male population is lower than that of women. From 2010 to 2012 the population of women was $51 \%$ while the male population was $49 \%{ }^{\left({ }^{(8)}\right.}$

The age of the research subjects in this study was classified according to the classification of Undang-Undang Kesejahteraan Sosial nomor 13 tahun 1998, the middle age group (45-54 years), early elderly (55 64 years), elderly ( $>65$ years), and the elderly at risk ( $>70$ years) . ${ }^{(9)}$ In this study only the elderly from the age of 60 years were included as research subjects. The results of the study as shown in table 2 show that the distribution of the elderly at the Posyandu Lansia Mekar Sari Surabaya was dominated by the elderly at risk ( $>70$ years) with a percentage of $41.9 \%$.
The distribution of the level of physical activity of the elderly at the Posyandu Lansia Mekar Sari Surabaya tends to be dominated by moderate intensity with a percentage of $58.1 \%$.

The results of the study as shown in table 4 about the distribution of pain scale showed that as much as $16.3 \%$ of the elderly experienced severe pain with a value of 7-10 according to measurements with NRS while mild and moderate scale pain had the largest percentage of $34.9 \%$ each.

The results of the Rank Spearman test, Sig. ( 2 tailed) is $0.382(>0.05$ suggest that there was no significant relationship between physical activity and pain scale. In this study, factors that influenced this outcome were the subjectivity of the results of questionnaire interviews, the limited number of research subjects, and the limitations of collecting additional data.

Study in Japan by Masamitsu Kamada et al. examined the relationship between the level of physical activity and the incidence of chronic low back pain and chronic knee pain. The results showed no significant correlation ( $p>0.05)$. They found that the incidence of pain was associated with a history of injury, drug use, and a history of consultation with a specialist. $^{(10)}$ 
When analyzing the relationship between the level of physical activity with pain it is necessary to pay attention to body weight and a history of musculoskeletal injury because obesity (excess fat deposits) is one of the risk factors for knee osteoarthritis and chronic musculoskeletal pain.

This process explains that excessive physical activity can cause chronic musculoskeletal pain, especially in people who are overweight. History of injuries is also a risk factors for chronic musculoskeletal pain.

Excessive physical activity can increase the risk of musculoskeletal injuries and injuries can cause a person to reduce physical activity, which results in increased body weight. ${ }^{10}$ However, in this study body weight was not investigated in relation to the musculoskeletal pain scale.

This is the reason why weight and history of injury need to be considered in analyzing the level of physical activity and pain.

In general, history of injury is only observed for studies of the risk of knee osteoarthritis, while studies on the relationship of physical activity and musculoskeletal pain do not involve a history of injury. Adults with a history of musculoskeletal pain tend to consult a doctor and take medication to treat pain.
Both of these can affect the patient's pain scale. $^{(10)}$

\section{CONCLUSION}

Based on data and analysis above, some conclusions can be drawn:

1. An overview of the level of physical activity of the elderly at the Posyandu Mekar Sari Surabaya can be classified as active with several variations in the level of physical activity (14\% mild, $58.1 \%$ moderate, and $27.9 \%$ heavy). This level of activity is dominated by the elderly at risk ( $>70$ years).

2. An overview of the elderly pain scale at the Posyandu Mekar Sari Elderly Surabaya on a mild and moderate scale has the same percentage of $34.9 \%$.

3. The Spearman Rank correlation test with SPSS shows the results there is no relationship between the level of physical activity of the elderly with the scale of pain in the elderly at the Posyandu Lansia Mekar Sari Surabaya with a probability value $\mathrm{p}=$ 0.382 .

\section{REFERENCES}

1. Kementrian Kesehatan RI. Buletin jendela data dan informasi kesehatan. 2013; h.40.

2. RI PD dan IKK. Situasi lanjut usia (lansia). InfoDATIN (Internet). 2016; h.12. (dikutip 2017 Mar 3). Diunduh dari 
http://www.depkes.go.id/download.ph p? file $=$ download/pusdatin/infodatin/in fodatinlansia2016/pdf

3. Cavalieri TA. Management of Pain in Older Adults. The Journal of the American Ostepathic Association (JAOA). 2005. Diunduh dari http://jaoa.org/

4. Sofaer B, Moore AP, Holloway I, Lamberty JM, Thorp TAS, O’Dwyer J. Chronic pain as perceived by older people: a quantitative study. 2005; h.463.

5. Rachmawati MR, Diana $\mathrm{S}$, Purnamawati T, Magdalena W. Nyeri musculoskeletal dan hubungannya dengan kemampuan fungsional fisik pada lanjut usia. 2006. h.180.

6. Nahin RL. Estimates of pain prevalence and severity in adults: United States, 2012. Journal of Pain. 2016;16(8): h.769-780.

7. World Health Organization (WHO). Physical activity and older adults (Internet). 2016;(dikutip 2017 Mar 3). Diunduh dari http://www.who.int/dietphysicalactivit $\mathrm{y} /$ factsheet olderadults/en/

8. Sastroasmoro S, Ismael S. Dasar-dasar metodologi penelitian klinis. 1st ed. Jakarta: Bagian Ilmu Kesehatan Anak, Fakultas Kedokteran, Universitas Indonesia; 1995. h.66, 70-1.

9. Badan Pusat Statistik Surabaya. Persentase Pebandingan Jumlah Penduduk Laki-laki dan Perempuan Tahun 2009-2012 [Internet]. Surabayakota.bps.go.id. 2017 [cited 4 November 2017]. Available from: https://surabayakota.bps.go.id/linkTab elStatis/view/id/343

10. Kamada M, Kitayuguchi J, Lee I, Hamano $\mathrm{T}$, Imamura $\mathrm{F}$, Inoue $\mathrm{S}$ et al. Relationship Between Physical Activity and Chronic Musculoskeletal Pain Among Community-Dwelling Japanese Adults. Journal of Epidemiology. 2014;24(6):474-483. 